\title{
PURIFICATION OF HISTAMINE RECEPTOR (VII) REASSESSMENT OF SPECIFICITY OF RADIOACTIVE DIBENAMINE TO LABEL $\mathrm{H}_{1}$ RECEPTORS
}

\author{
Masaatsu UCHIDA \\ Department of Molecular Pharmacology, \\ Meiji College of Pharmacy, Nozawa, Setagaya-ku, Tokyo 154, Japan
}

Accepted June 4, 1979

In a foregoing paper (1), a method for labeling histamine $H_{1}$ receptor with radioactive dibenamine in the smooth muscle of cat small intestine was proposed. We found $7 \mathrm{p}$ moles bound dibenamine per $\mathrm{mg}$ protein of the total tissue homogenate and $40 \mathrm{p}$ moles per $\mathrm{mg}$ protein of the plasma membrane fraction. This communication deals with reconsideration on the receptor specificity of this bound dibenamine or, more accurately, on the selectivity of $\mathrm{H}_{1}$ receptor. The procedure in the previous paper (1) involved 'double protection" which means the two-step application of protectors against dibenamine: the first protection was the usual one with protective antihistamine, promethazine, and the second was cross protection of non-specific sites with drugs having negligible antihistaminic actions in the doses used, thioridazine and atropine. Muscle strips protected with promethazine against nonradioactive dibenamine were treated with ${ }^{3} \mathrm{H}$-dibenamine in the presence of these second protectors. The second protectors were to cover non-specific sites which had been protected non-specifically with promethazine from non-radioactive dibenamine. The first nonradioactive dibenamine was 4 times higher in concentration than the second ${ }^{3} \mathrm{H}$-dibenamine.

The difficulty is in determining the proportion of non-specific sites labeled with ${ }^{3} \mathrm{H}$ dibenamine presumed to represent receptor-specific binding, as reported previously (2). This problem arises from the non-saturable mode of binding of dibenamine to the tissue. Moran et al. (3) reported that new nucleophilic groups were successively uncovered to react with dibenamine after dibenamine had bound to those groups already present. In our method, ${ }^{3} \mathrm{H}$-dibenamine is considered to bind to the newly uncovered groups even after non-radioactive dibenamine reacts with the non-receptor sites already present. To assess non-receptor binding of ${ }^{3} \mathrm{H}$-dibenamine, ${ }^{3} \mathrm{H}$-dibenamine $\left(1 \times 10^{-6} \mathrm{M}\right.$, whose concentration was sufficient to suppress histamine-induced contraction in our preparations) was applied in the presence of promethazine $\left(3 \times 10^{-7} \mathrm{M}\right)$, thioridazine $\left(3 \times 10^{-7} \mathrm{M}\right)$ and atropine $\left(3 \times 10^{-7}\right.$ M) after application of non-radioactive dibenamine $\left(4 \times 10^{-6} \mathrm{M}\right)$ under protection with promethazine $\left(3 \times 10^{-7} \mathrm{M}\right)$ as shown in Fig. 1-A. The radioactivity of bound ${ }^{3} \mathrm{H}$-dibenamine was compared to the sample from the same cat labeled in the presence of thioridazine and atropine but without promethazine as shown in Fig. 1-B. Thioridazine and atropine did not protect the histamine $\mathrm{H}_{1}$ receptor under these conditions, however protection was evident with promethazine. The labeled muscle strips were homogenized and fractionated as described previously (4). ${ }^{3} \mathrm{H}$-Dibenamine $(58.5 \mathrm{Ci} / \mathrm{mole})$ was prepared as already reported 
Longitudinal smooth muscle of cat small intestine.

Cut longitudinally into two strips and suspend in organ baths bubbled with $95 \% \mathrm{O}_{2}+5 \% \mathrm{CO}_{2} \mathrm{kept}$ at $32{ }^{\circ} \mathrm{C}$. Repeatedly contract with histamine.

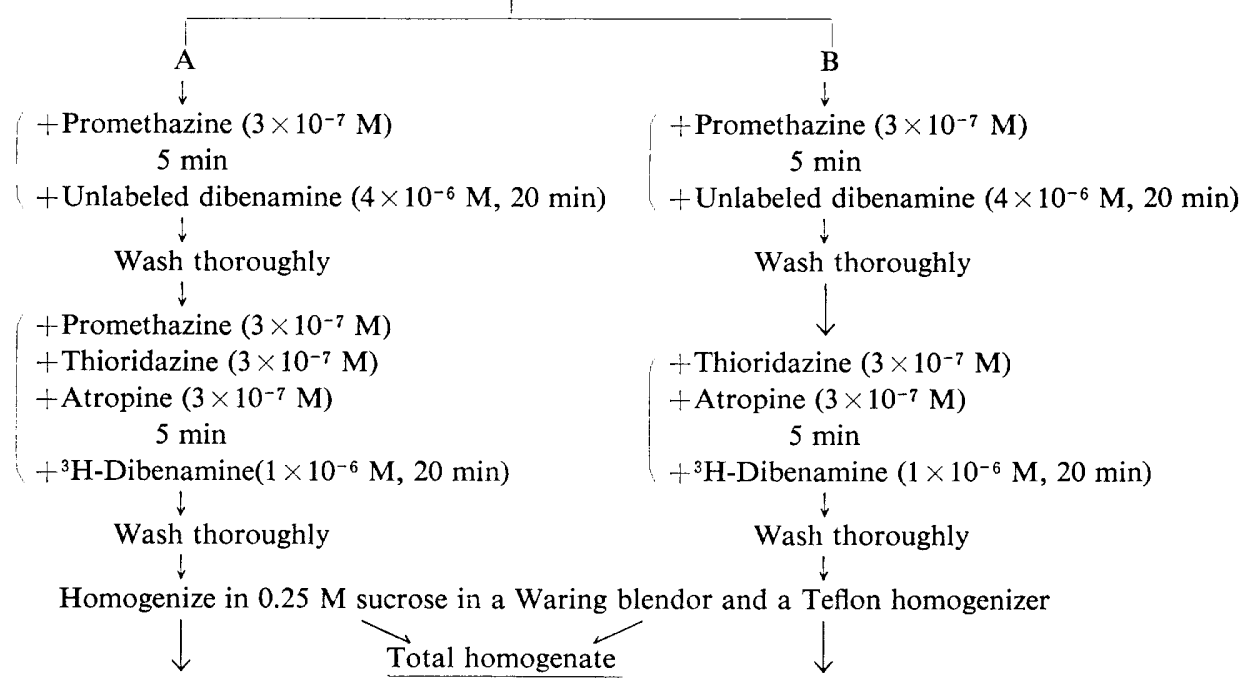

Centrifuge at $15,000 \times \mathrm{g}$ for $30 \mathrm{~min}$ and filter the supernatant through gauze

Apply the supernatant to a sucrose density gradient and centrifuge at

$25,000 \mathrm{rpm}$ in a Hitachi rotor RPS 25 for $120 \mathrm{~min}$

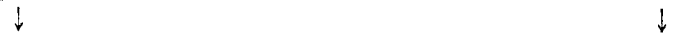

Take the layer on the interface between $\mathrm{d}=1.03$ and 1.10 and wash with $\mathrm{KCl}$

( $0.6 \mathrm{M}$ in final concentration) and centrifuge down at $75,000 \times \mathrm{g}$ for $90 \mathrm{~min}$

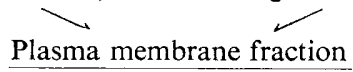

FIG 1. Procedures for labeling with ${ }^{3} \mathrm{H}$-dibenamine. An alley cat was anesthetized with pentobarbital sodium $(35 \mathrm{mg} / \mathrm{kg})$ and exanguinated. Small intestines were removed and the longiutudinal layer of smooth muscle was carefully peeled off. Procedure $A$ was for labeling non-receptor sites which were uncovered after unlabeled dibenamine had bound to non-receptor sites already present. Procedure $B$ was for labeling both receptor sites and non-receptor sites. Thus the difference between the two procedures will represent the receptor label whose proportion to non-receptor ones is now under investigation.

(1) and the bound radioactivity was counted after oxidizing the samples in a Model 306 Tricarb oxidizer (Packard Instrument) (1). We could determine the radioactivity of $0.20 \mathrm{p}$ moles of ${ }^{3} \mathrm{H}$-dibenamine per $\mathrm{mg}$ protein with confidence limits of $0.16-0.22 \mathrm{p}$ moles $(\alpha=0.01$, $\mathrm{N}=10$ ) (5) when the non-labeled muscle homogenate (10 mg protein) on a filter paper was oxidized after addition of $2.0 \mathrm{p}$ moles of ${ }^{3} \mathrm{H}$-dibenamine. Protein was determined by the micro-biuret reaction (6).

The results are shown in Table 1. Although the values varied widely among the cats, the difference of the amount of bound dibenamine between the samples labeled in the presence of promethazine (Procedure $A$ ) and those in its absence (Procedure $B$ ) was $0.9 \pm 0.2 \mathrm{p}$ moles per protein of the total homogenate or $3.4 \pm 0.8 \mathrm{p}$ moles per $\mathrm{mg}$ protein of the plasma 
TABLE 1. Bound ${ }^{3} \mathrm{H}$-dibenamine to the total homogenate and to the plasma membrane fraction from smooth muscle of cat small intestine

\begin{tabular}{lrrrrrrrr}
\hline & \multicolumn{7}{c}{ Bound ${ }^{3}$ H-dibenamine (p moles/mg protein) } \\
\cline { 2 - 9 } Total homogenate & 1 & 2 & 3 & 4 & 5 & 6 & 7 & mean \pm SE. \\
\hline Procedure A & 2.5 & 3.6 & 4.3 & 5.3 & 5.9 & 5.9 & 6.8 & $4.9 \pm 0.6$ \\
Procedure B & 3.6 & 4.2 & 4.7 & 5.6 & 6.9 & 7.5 & 8.2 & $5.8 \pm 0.6$ \\
Difference & 1.1 & 0.6 & 0.4 & 0.3 & 1.0 & 1.6 & 1.4 & $0.9 \pm 0.2$ \\
\hline $\begin{array}{l}\text { Plasma membrane } \\
\quad \text { fraction }\end{array}$ & I & II & III & IV & V & VI & mean \pm S.E. \\
\hline Procedure A & 9.2 & 12.4 & 19.8 & 20.2 & 22.5 & 23.2 & $17.9 \pm 2.3$ \\
Procedure B & 10.4 & 16.3 & 25.8 & 22.9 & 23.9 & 28.6 & $21.3 \pm 2.7$ \\
Difference & 1.2 & 3.9 & 6.0 & 2.7 & 1.4 & 5.4 & $3.4 \pm 0.8$ \\
\hline
\end{tabular}

The muscles were labeled as described in Fig. 1. Procedures $A$ and $B$ were indicated in the figure and 'difference' means the difference of the amount of bound ${ }^{3} \mathrm{H}$-dibenamine between the samples treated according to Procedure $A$ and those to Procedure $B$. Standard error (S.E.) for 'difference' was calculated from each value of 'difference'. On the total homogenates, 7 cats were used and on the plasma membranes 6 cats were used. The result from each cat is shown in the column under the numeral (Arabic for the homogenate and Roman letters for the membrane fraction).

membrane fraction. There may have been a bulk of dibenamine bound to non-receptor sites in our previous trial (1) because of the non-saturable mode of dibenamine binding.

Hill et al. (7) used ${ }^{3} \mathrm{H}$-mepyramine for binding studies in the whole homogenate of the smooth muscle of guinea pig small intestine and reported that the specific binding was 0.05-0.3 p moles per $\mathrm{mg}$ of the homogenate (8). We studied the binding of ${ }^{3} \mathrm{H}$-histamine to the plasma membrane fraction of the smooth muscle of cat small intestine, in which the binding capacity was $1.0-2.5 \mathrm{p}$ moles per $\mathrm{mg}$ protein of the fraction. The $\mathrm{K}_{\mathrm{D}}$ value was $1-3 \times 10^{-7} \mathrm{M}(2)$. These values were obtained by applying a model with two orders of sites to the Scatchard plots and neglecting the sites with the highest affinity. But when these high affinity sites were picked out and plotted reciprocally according to Lineweaver-Burk equation, the binding capacity was $0.2-1.0 \mathrm{p}$ moles per mg protein of the membrane fraction and $K_{D}$ was $0.3-1.0 \times 10^{-8} \mathrm{M}$. Thus our previous values might have been overestimated. Although these binding data were obtained in vitro on dispersed cells or on their sub-fraction, these values were about $1 / 2-1 / 15$ of the present results obtained by application of the irreversible antagonist to the living tissue. Thus, even with precautions there are limitations to using radioactive dibenamine. However, such do provide a criterion for further fractionation of labeled materials or for another trial to label $\mathrm{H}_{1}$ receptor with a more selective alkylator. For example, diphenhydramine mustard (9) has about a 7 -fold higher affinity for $\mathrm{H}_{1}$ receptor than dibenamine whose apparent affinity for $\mathrm{H}_{1}$ receptor after $20 \mathrm{~min}$ incubation is about $1 / 40$ of mepyramine.

\section{REFERENCES}

1) UCHIDA, M.: Purification of histamine receptor (VI). An improved double labeling method with "double protection". Japan. J. Pharmacol. 27, 781-789 (1977) 
2) UCHida, M.K.: Purification of histamine $\mathrm{H}_{1}$ receptor. Gen. Pharmacol. 9, 145-153 (1978)

3) Moran, J.F., May, M., Kimelberg, H. and Triggle, D.J.: Studies on the noradrenaline alpha-receptor. I. Techniques of receptor isolation. Mol. Pharmacol. 3, 15-27 (1967)

4) Uchida, M. AND Takagi, K.: Purification of histamine receptor (III). Characterization of receptor rich membrane fraction of small intestinal smooth muscle of the cat. Japan. J. Pharmacol. 27, 1-7 (1977)

5) Cochran, W.G. And Cox, G.M.: Experimental Designs, 2nd ed., p. 50-53, John Wiley \& Sons Inc., New York (1957)

6) ItZAhKi, R.F. AND Gill, D.M.: A micro-biuret method for estimating protein. Analyt. Biochem. 9, 401-410 (1964)

7) Hill, S.J., Young, J.M. and Marrian, D.H.: Specific binding of ${ }^{3} \mathrm{H}$-mepyramine to histamine $\mathrm{H}_{1}$ receptor in intestinal smooth muscle. Nature 270, 361-362 (1977)

8) Hill, S.J. ANd Young, J.M.: Evidence for the presence of histamine $\mathrm{H}_{1}$-receptor in guinea pig brain. Brit. J. Pharmacol. 63, 394P-395P (1978)

9) Ohta, K., TAKayanagi, I. AND TAKagi, K.: Studies on affinities of benzilylcholine mustard and diphenhydramine mustard for acetylcholine and histamine receptors. Pharmacometrics 11, 365-369 (1976) 